\title{
Three-dimensional modelling of the femur and humerus in adult male guinea pigs (guinea pig) with computed tomography and some biometric measurement values
}

\author{
M.O. Dayan, K. Beşoluk, E. Eken, S. Aydoğdu, N. Turgut \\ Department of Anatomy, Faculty of Veterinary, Selçuk University, Konya, Turkey
}

[Received: 16 October 2018; Accepted: 5 December 2018]

Background: Guinea pig is a species belonging to the Caviidae family of the Rodentia order and is frequently used in experimental studies. Biomedical imaging methods are used in the diagnosis and treatment of many diseases in medicine. Among these methods, computed tomography (CT) is one of the most important imaging methods. In this study, it was aimed to perform the three-dimensional (3D) modelling of the CT images, obtained from the humerus and femur in the guinea pigs, via the MIMICS programme, and to make some biometric measurements regarding the bones over these models.

Materials and methods: In the present study, 12 male adult guinea pigs were used. The soft tissue on the humerus and femur bones of the guinea pigs was removed. After this procedure, CT images at a $0.5 \mathrm{~mm}$-thickness were obtained from the animals. The images were recorded in DICOM format. Then, the reconstruction process was performed from the images by using the $3 D$ modelling programme MIMICS ${ }^{\circledR}$ 13.1. On the 3D model of the humerus and femur (right-left), volumes, surface areas and lengths as well as other biometric parameters were measured separately, and the values were recorded. In addition, measurements of the bones were made with the help of a digital calliper.

Results: Among the parameters obtained from 3D models, a statistical difference was observed between the right and left cortical thicknesses of the femur from the measurements of calliper and the right and left humerus volumes $(p<0.05)$; whereas, no statistical difference was found in other parameters of both measurements $(p>0.05)$.

Conclusions: It can be stated that CT and 3D modelling can be used for the measurement of some parameters in the long bones of the guinea pigs. (Folia Morphol 2019; 78, 3: 588-594)

Key words: computed tomography, femur, humerus, guinea pig, three-dimensional reconstruction

\section{INTRODUCTION}

Guinea pig is a species belonging to the Caviidae family of the Rodentia order [22]. Guinea pigs that are frequently used in the experimental studies such as immunology, toxicology, pharmacology, and physiology are native to South America and their wild ones

Address for correspondence: Associate Professor M.O. Dayan, Department of Anatomy, Faculty of Veterinary, Selçuk University, Konya, Turkey e-mail: modayan@selcuk.edu.tr 
are rodents that inhabit in Peru [41]. Their heads are quite large and their ears and tails are quite small [22]. They are herbivores. Adult guinea pigs have a body length of $27-33 \mathrm{~cm}$ and weigh of 700-1200 $g$ [34]. They live for 2-8 years [41].

Bones, which are the passive elements of the locomotor system, are composed of organic and inorganic substances. In a guinea pig that has completed its growth, $1 / 3$ of the bone is organic substances (ossein); whereas, $2 / 3$ is inorganic substances $(85 \%$ - calcium phosphate, $10 \%$ - calcium carbonate, magnesium phosphate, calcium fluoride). While the organic substances provide the elasticity of the bone, inorganic substances provide hardness and durability to the bone $[12,34]$. Appendiculare skeleton is divided into two parts as bones of thoracic limb and pelvic limb. One of the bones of thoracic limb is the humerus. The longest bone of the body, which is included in the bones of the pelvic limb, is the femur $[12,26]$.

Morphometry is a research method which examines the shape differences of the objects and organisms and the correlations of the shape differences with other variations. This method is sometimes used to analyse the correlation between gender and growth factors of the species and sometimes the effects of the treatment applied [6, 36]. Conventional morphometry is the multiple variance statistical analysis that is performed with quantitative (length, width, height) variables [16]. Depending on the environmental components and the genetic structure, the differences in the growth of the living being can be easily revealed by morphology and morphometric studies [39].

Biomedical imaging methods are used in the diagnosis and treatment of many diseases in medicine $[13,40]$. The working principle of computed tomography (CT), which is one of the medical imaging methods, is based on the detection of the non-absorbable part of the collimated X-rays passing through any part of the body in the tissues by the detectors as well as the conversion of the electrical signals into a cross-sectional image by means of computer operations [21]. With this method, the structures are displayed in a cross-sectional view and the images are much more detailed than the X-ray [1]. In recent years, CT has played an important role in the anatomical studies and in the correct diagnosis of the diseases in veterinary medicine. In addition to the diagnosis of diseases, $\mathrm{CT}$ is also used effectively in many biometric researches $[13,27,28]$.
Three-dimensional (3D) formation of the transversal and longitudinal sections obtained from CT and other medical imaging methods is referred as reconstruction $[2,15,32]$. Thanks to this method, organisation and processing of the $3 \mathrm{D}$ information obtained by the reconstructions of the first cross-sectional images and enabling them to be presented in various shapes have become an acceptable method in medical sciences, especially in anatomy, surgical and clinical treatment $[14,20,31,38]$. Anatomical details that cannot be observed in 2D images can be observed in more details with 3D reconstructed models. Today, MIMICS is one of the computer software used to create 3D models of two-dimensional (2D) images that are obtained from CT and magnetic resonance imaging methods. This software is a medical imaging and control system developed by Materialise (Mimics, Materialise Inc., Leuven, Belgium) for the 3D modelling of anatomical structures. One of the most important features that distinguishes MIMICS from other 3D modelling software is that it is a segmentation programme using Hounsfield values $[3,15$, $18,24,31,33]$.

In recent years, various studies have been conducted on the 3D modelling of anatomical structures in the field of veterinary anatomy. In a study conducted on the pelvic cavity of New Zealand rabbits, pelvis diameters and pelvic inclination were measured on a 3D model and evaluated in terms of gender. It has been suggested that the models obtained by the present study will contribute to the anatomical training and also in the diagnosis and treatment of diseases and to the knowledge of today's anatomy [30]. In addition, 3D modelling of penile urethra, stomach and intestine, respiratory system, paranasal sinus and antebrachium was performed in the rabbits $[9,10,19,29,31]$. In addition, a 3D model of the nasal airway was also performed in Nycticebus pygmaeus (Slow loris) [11]. 3D modelling of the thick filaments of the cardiac muscle in zebrafish, paranasal sinuses and diverticulum tubae auditivae in the horses and the nephron in the rat was done $[4,5,8,17]$. As a result, it is seen that the 3D modelling method has started to be frequently used in the field of veterinary anatomy.

In the literature reviews, it was observed that CT and 3D modelling of the femur and humerus, which are the long bones of the body, in the guinea pigs, and the information regarding the measurements to be obtained over these models were limited $[35,40]$. 
The purpose of the present study is to perform the 3D modelling of the CT images obtained from the humerus and femur in guinea pigs via the MIMICS programme and to calculate some of the biometric measurements of the bones such as volume, surface area and length over these models.

\section{MATERIALS AND METHODS}

In the study, 12 adult male guinea pigs were used. The study procedure was approved by the Ethics Committee of Selçuk University Faculty of Veterinary Medicine $(09 / 03 / 2017,2017 / 26)$. After the soft tissue on the humerus and femoral bones of the guinea pigs was removed, morphological differences were recorded. After this procedure, $\mathrm{CT}$ images were obtained from the animals at $0.5-\mathrm{mm}$ thickness. The images were recorded in DICOM format. Then, the reconstruction process was performed from the images transferred to a portable external disk by using the MIMICS ${ }^{\circledR} 13.1$ (The Materialise Group, Leuven, Belgium), a 3D modelling programme (Fig. 1).

In the reconstruction processes, the bone edges to be selected by using the "Thresholding" command from the "Segmentation" menu of MIMICS programme were automatically masked. Bones that could not be masked were corrected manually by the computer mouse by selecting the "Edit mask" command. After the manual correction process was completed, independent masking was reapplied to the selected bone by the "Region Growing" command. Finally, 3D modelling was performed by the "Calculate 3D" command. On the 3D model of the humerus and femur (right-left), their volumes, surface areas and lengths as well as other biometric parameters were automatically measured separately by using the "Info" command and the values were recorded. In addition, measurements of the bones were made by the help of a digital calliper. The diameter and cortical thickness of the humerus and femur were measured from the diaphysis section of the bones (Fig. 2).

Measurements performed on the bone (Figs. 3, 4):

-1 : maximum length of the humerus;

-2 : maximum length of the femur;

- 3: proximal width of the humerus;

- 4: proximal width of the femur;

- 5: distal width of the humerus;

- 6: distal width of the femur;

- 7: cortical thickness of the humerus;

- 8: cortical thickness of the femur;

-9 : medullary cavity diameter of the humerus;

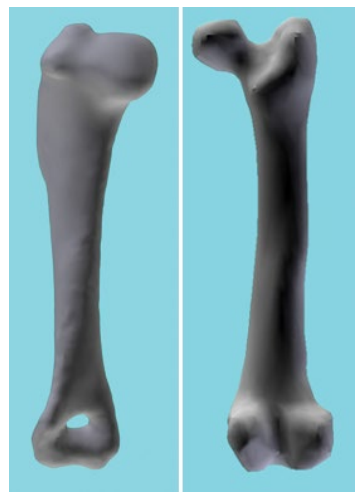

Figure 1. Three-dimensional models of the humerus and femur.

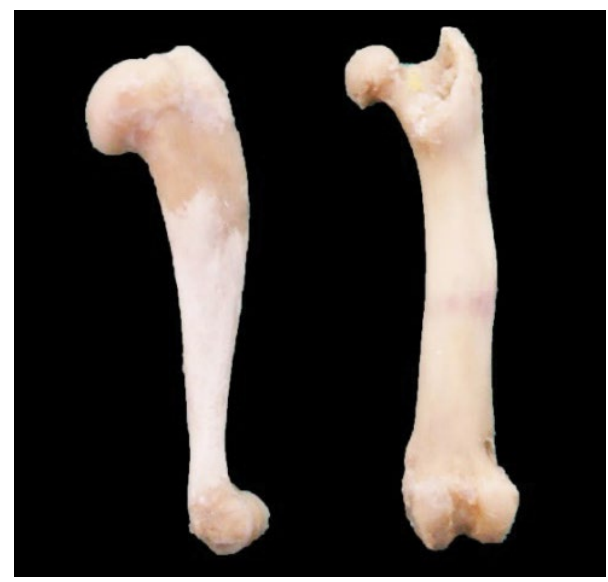

Figure 2. Humerus (left) and femur (right).

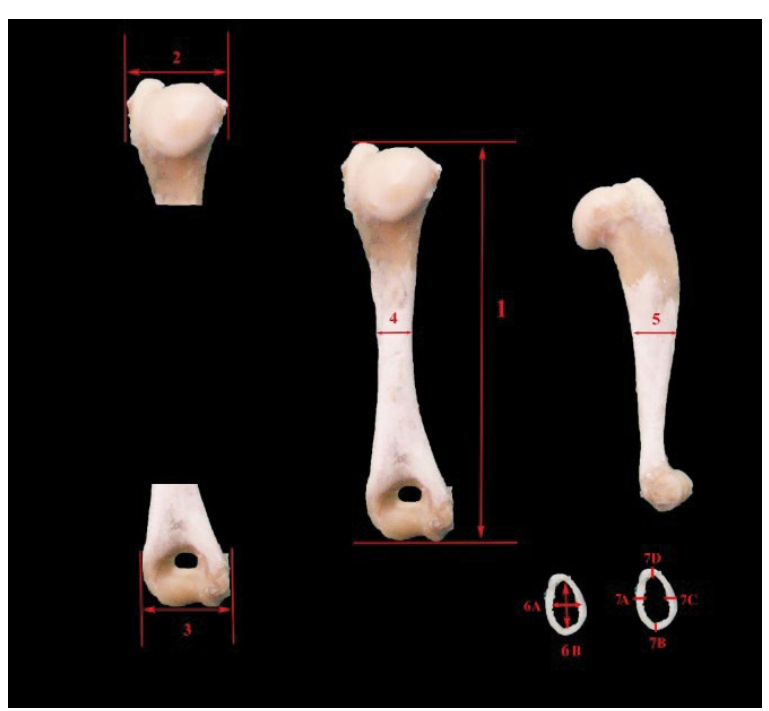

Figure 3. Measurement points taken from the humerus; $1-$ maximum length of the humerus; 2 - proximal width of the humerus; 3 - distal width of the humerus; 4 - diaphysis diameter of the humerus (medio-lateral); 5 - diaphysis diameter of the humerus (cranio-caudal); 6 - medullary cavity diameter of the humerus $[6 \mathrm{~A}$ (mediolateral) $+6 \mathrm{~B}$ (craniocaudal)/2]; 7 - cortex thickness of the humerus [7A (medial) $+7 \mathrm{~B}$ (lateral) $+7 \mathrm{C}$ (caudal) $+7 \mathrm{D}$ (cranial)/4] . 


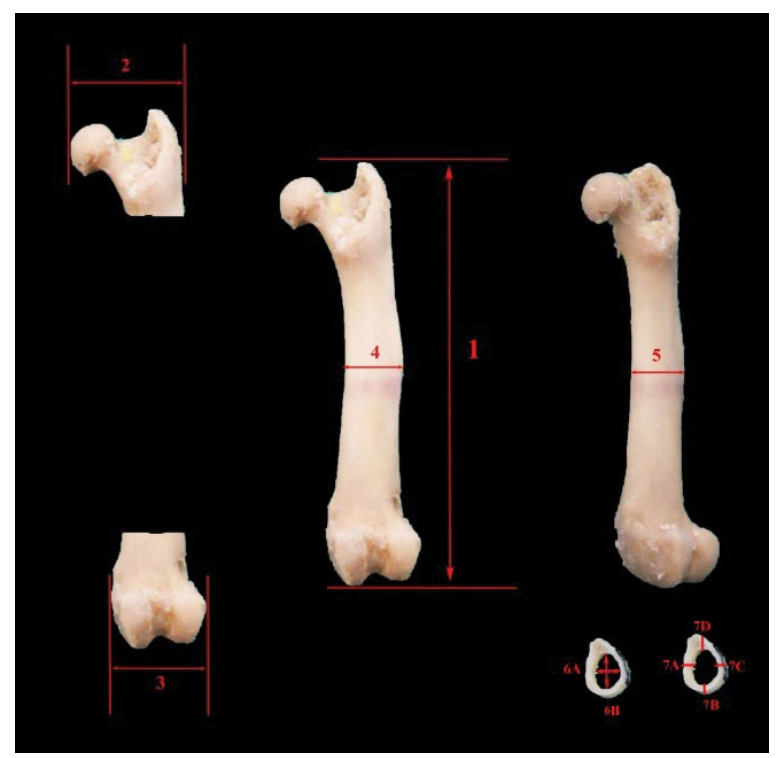

Figure 4. Measurement points taken from the femur; 1 - maximum length of the femur; 2 - proximal width of the femur; 3 - distal width of the femur; 4 - diaphysis diameter of the femur (medio-lateral); 5 - diaphysis diameter of the femur (cranio-caudal); 6 - medullary cavity diameter of the femur [ $6 \mathrm{~A}$ (mediolateral) $+6 \mathrm{~B}$ (craniocaudal)/2]; 7 - cortex thickness of the femur [7A (medial) $+7 \mathrm{~B}$ (lateral) $+7 \mathrm{C}$ (caudal) $+7 \mathrm{D}$ (cranial) $/ 4$ ] .

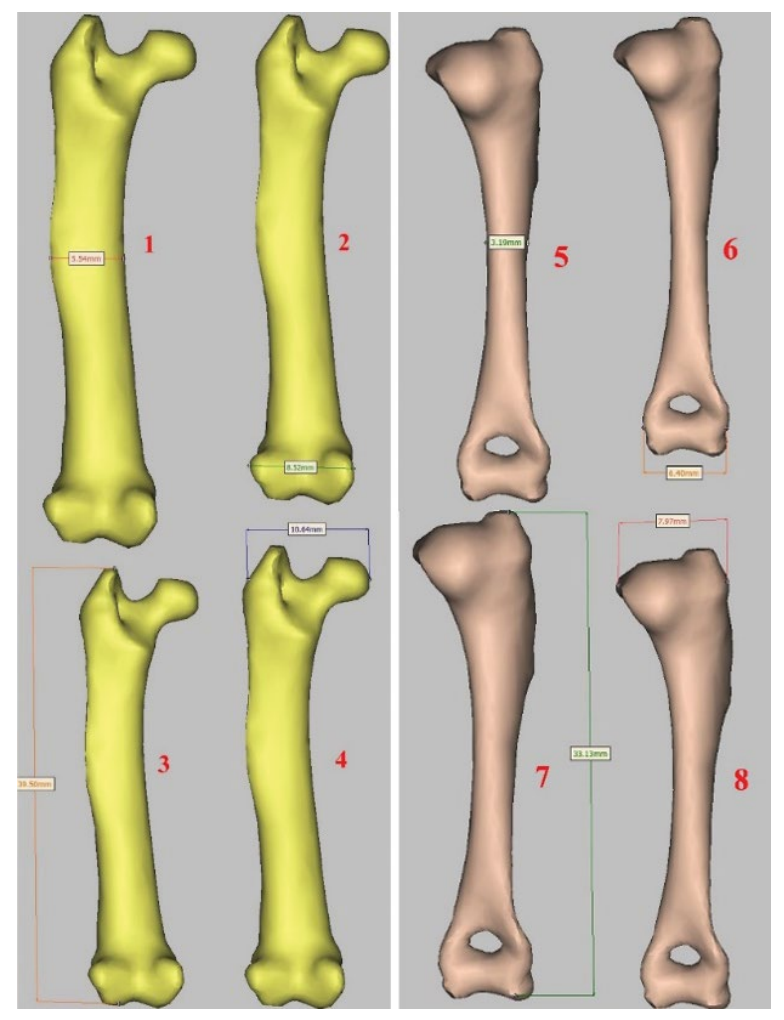

Figure 5. Measurements taken from the three-dimensional models of the femur and the humerus; 1 - diaphysis diameter of the femur (medio-lateral); 2 - distal width of the femur; 3 - maximum length of the femur; 4 - proximal width of the femur; 5 - diaphysis diameter of the humerus; 6 - distal width of the humerus; $7-$ maximum length of the humerus; 8 - proximal width of the humerus.
- 10: medullary cavity diameter of the femur;

- 11: diaphysis diameter of the humerus;

- 12: diaphysis diameter of the femur.

On the 3D model, above mentioned parameters $7,8,9$, and 10 could not be measured.

Anatomic terms used in this study were written by taking Nomina Anatomica Veterinaria as a reference [25].

Normality test was applied on the measurements taken on the 3D model and the morphometric measurements obtained from the bones via the MIMICS programme. While the normally distributed values were evaluated by the paired t test, the values that did not show normal distribution were evaluated by the Wilcoxon test (SPSS 22.0). The value of $p<0.05$ was accepted as the statistically significant limit.

\section{RESULTS}

It was observed that the head of the humerus in the proximal extremity section of the shoulder joint with the scapula was quite large in guinea pig. Deltoid tuberosity was not significant. Radial fossa and olecranon fossa were associated with supratrochlear foramen.

It was observed that greater trochanter in the proximal extremity section of the femur was higher than the head of the femur and lesser trochanter was a circular crest. The presence of fovea of the head was determined on the articular surface of the femoral head. On the other hand, in the distal extremity section, each condyle had articular surfaces specific to articulation of the sesamoid bones.

Table 1 shows the measurement values performed on the 3D models of the humerus and femur in the study. While there was a statistical difference in the right and left humeral volume $(p=0.046)$ from the parameters obtained from 3D models, no difference was determined in other parameters $(p>0.05)$.

Table 2 shows measurement values of the humerus and femur measured with digital calliper. While a statistically significant difference was observed between the cortical thickness of the femur ( $p<0.05$ ), no difference was found in other parameters $(p>0.05)$.

\section{DISCUSSION}

While the guinea pig is being fed as an exotic animal, it is an animal model that is used in many experimental studies in the field of health [41]. The humerus and the femur are the two long bones that are frequently preferred in morphometric studies [23]. CT and 3D modelling are currently used in the 
Table 1. Measurement results performed on the three-dimensional models of the humerus and femur in adult male guinea pigs

\begin{tabular}{lccc}
\hline Parameters & Right & Left & P \\
\hline Maximum length of the humerus [mm] & $32.22 \pm 1.16$ & $32.15 \pm 0.85$ & $>0.05$ \\
Maximum length of the femur [mm] & $38.75 \pm 1.65$ & $38.61 \pm 1.83$ & $>0.05$ \\
Proximal width of humerus [mm] & $7.72 \pm 0.74$ & $7.79 \pm 0.41$ & $>0.05$ \\
Proximal width of the femur [mm] & $10.69 \pm 0.89$ & $9.74 \pm 0.61$ & $>0.05$ \\
Distal width of the humerus [mm] & $6.28 \pm 0.59$ & $6.17 \pm 0.30$ & $>0.05$ \\
Distal width of the femur [mm] & $8.16 \pm 0.38$ & $7.80 \pm 0.41$ & $>0.05$ \\
Diaphysis diameter of humerus (lateral-lateral) [mm] & $2.89 \pm 0.4$ & $3.10 \pm 0.30$ & $>0.05$ \\
Diaphysis diameter of the femur (cranio-caudal) [mm] & $4.07 \pm 0.33$ & $4.16 \pm 0.40$ & $>0.05$ \\
Diaphysis diameter of the femur (lateral-lateral) [mm] & $5.03 \pm 0.49$ & $5.09 \pm 0.55$ & $>0.05$ \\
Diaphysis diameter of the humerus (cranio-caudal) [mm] & $3.78 \pm 0.40$ & $4.11 \pm 0.30$ & $>0.05$ \\
Surface area of the humerus [mm²] & $515.74 \pm 59.63$ & $597.49 \pm 140.24$ & $>0.05$ \\
Surface area of the femur [mm²] & $823.88 \pm 84.70$ & $802.54 \pm 158.88$ & $>0.05$ \\
Volume of the humerus [mm $\left.{ }^{2}\right]$ & $447.70 \pm 52.70$ & $601.85 \pm 183.50$ & $<0.046$ \\
Volume of the femur [mm3] & $770.12 \pm 148.18$ & $853.84 \pm 85.88$ & $>0.05$ \\
\hline
\end{tabular}

Data are shown as mean \pm standard deviation.

Table 2. Morphometric measurement results of the humerus and femur in adult male guinea pigs

\begin{tabular}{lccc}
\hline Parameters & Right & Left & P \\
\hline Maximum length of the humerus [mm] & $32.92 \pm 0.83(32.78)$ & $32.88 \pm 0.63(32.70)$ & $>0.05$ \\
Maximum length of the femur [mm] & $39.66 \pm 1.47(39.52)$ & $39.48 \pm 1.70(39.36)$ & $>0.05$ \\
Proximal width of the humerus [mm] & $8.23 \pm 0.52$ & $8.36 \pm 0.34$ & $>0.05$ \\
Proximal width of the femur [mm] & $10.00 \pm 0.30$ & $9.92 \pm 0.17$ & $>0.05$ \\
Distal width of the humerus [mm] & $7.01 \pm 0.52(6.92)$ & $7.05 \pm 0.66(6.77)$ & $>0.05$ \\
Distal width of the femur [mm] & $8.40 \pm 0.20(8.34)$ & $8.40 \pm 0.40(8.37)$ & $>0.05$ \\
Diaphysis diameter of the humerus (lateral-lateral) [mm] & $2.91 \pm 0.16$ & $2.95 \pm 0.20$ & $>0.05$ \\
Diaphysis diameter of the humerus (cranio-caudal) [mm] & $4.11 \pm 0.28$ & $4.13 \pm 3.23$ & $>0.05$ \\
Diaphysis diameter of the femur (lateral-lateral) [mm] & $5.11 \pm 0.43$ & $5.22 \pm 0.35$ & $>0.05$ \\
Diaphysis diameter of the femur (cranio-caudal) [mm] & $3.95 \pm 0.30$ & $3.91 \pm 0.17$ & $>0.05$ \\
Cortex thickness of the humerus [mm] & $0.67 \pm 0.09$ & $0.74 \pm 0.15$ & $>0.05$ \\
Cortex thickness of the femur [mm] & $0.84 \pm 0.11$ & $0.76 \pm 0.10$ & $<0.039$ \\
Medullary cavity diameter of the humerus [mm] & $2.49 \pm 0.46$ & $2.30 \pm 0.36$ & $>0.05$ \\
Medullary cavity diameter of the femur [mm] & $3.36 \pm 0.25$ & $3.23 \pm 0.35$ & $>0.05$ \\
\hline
\end{tabular}

Data are shown as mean \pm standard deviation and (median).

diagnosis, and treatment of many diseases [13, 15, 20]. In addition, bone morphometric measurements are made with the help of the digital calliper [23]. In the present study, the humerus and femur bones of 12 adult male guinea pigs were modelled as 3D and various parameters were measured. Some morphometric parameters of the same bones that were measured by using a digital calliper were also evaluated.

In the present study, it was determined that while a statistical difference was observed in the left and right humeral volume parameters obtained from the data of 3D models (right: 447.70 ; left: $601.85, p=0.046$ ), no difference was observed in other parameters (maximum length of the humerus [mm] right: 32.22; left: 32.15 , maximum length of the femur [mm] right: 38.75; left: 38.61 , proximal width of the humerus [mm] right: 7.72 ; left: 7.79 , proximal width of the femur [mm] right: 10.69; left: 9.74, distal width of the humerus [mm] right: 6.28 ; left: 6.17 , distal width of the femur [mm] right: 8.16; left: 7.80, diaphysis diameter 
of the humerus (lateral-lateral) [mm] right: 2.89; left: 3.10, diaphysis diameter of the humerus (cranio-caudal) $[\mathrm{mm}]$ right: 4.07 ; left: 4.16 , diaphysis diameter of the femur (lateral-lateral) [mm] right: 5.03; left: 5.09, diaphysis diameter of the femur (cranio-caudal) [mm] right: 3.78; left: 4.11 , surface area of the humerus [mm²] right: 515.74; left: 597.49, surface area of the femur [mm²] right: 823.88; left: 802.54, volume of the femur [ $\left.\mathrm{mm}^{3}\right]$ right: 770.12 ; left: 853.84 ) (Table 1, $p>0.05)$. In the literature reviews, several studies in which CT was used in guinea pigs were accessed [7, 37,42 ], a limited number of studies investigating the humerus and femur were accessed. The humerus and femur lengths calculated by Witkowska et al. [40] in 1 -year-old guinea pigs via this model were similar to the present study. Pazvant [35] stated that the difference between the maximum lengths of the right and left humerus and the anterio-posterior diameter of the diaphysis was significant in the measurement results of the $\mathrm{CT}$ images of the guinea pig. Pazvant [35] reported that the difference observed in results of the measurement performed between medio-lateral and anterio-posterior diameters of the diaphysis of the femur on CT images of guinea pig was statistically significant; whereas, no such difference was determined in measurements performed on bone and model as a result of the study. The differences between the results of the study may be caused by the difference in methodology.

Among the measurements performed by means of the digital calliper in the present study, a statistically significant difference was found between right $(0.84$ $\mathrm{mm})$ and left $(0.76 \mathrm{~mm})$ cortical thickness of the femur $(p<0.05)$; whereas, no difference was found in other parameters (maximum length of the humerus $[\mathrm{mm}]$ right: 32.92; left: 32.88, maximum length of the femur [mm] right: 39.66; left: 39.48 , proximal width of the humerus [mm] right: 8.23 ; left: 8.36 , proximal width of the femur [mm] right: 10.00; left: 9.92, distal width of the humerus [mm] right: 7.01 ; left: 7.05 , distal width of the femur [mm] right: 8.40; left: 8.40, diaphysis diameter of the humerus (lateral-lateral) [mm] right: 2.91; left: 2.95, diaphysis diameter of the humerus (cranio-caudal) $[\mathrm{mm}]$ right: 4.11 ; left: 4.13 , diaphysis diameter of the femur (lateral-lateral) [mm] right: 5.11; left: 5.22, diaphysis diameter of the femur (cranio-caudal) [mm] right: 3.95; left: 3.91, cortex thickness of the humerus [mm] right: 0.67 ; left: 0.74 , medullary cavity diameter of the humerus [mm] right: 2.49 ; left: 2.30 , medullary cavity diameter of the femur [mm] right: 3.36 ; left: 3.23 )
(Table 2, p > 0.05). In the studies conducted between the sexes in guinea pigs, it has been specified that there is no difference in the maximum length of the right and left humerus on the direct osteometric and radiography images and the right and left values in all measurements of the femur $[34,35]$ and the femur and humerus lengths in both genders of nandrolone-administered rats [23].

\section{CONCLUSIONS}

In conclusion, it was determined that among the data obtained from 3D modelling, there was a statistical difference in the right and left humeral volume parameter and also in the right and left cortical thickness from the measurements performed by the digital calliper; whereas, no statistical difference was observed in other parameters. It can be asserted that CT can be used in the modelling of both bones; however, $3 \mathrm{D}$ modelling in some parameters in small bones and micro CT in measurements may be more beneficial.

\section{Acknowledgements}

A portion of this study's abstract was presented in " $1^{\text {st }}$ International Health Science and Life Congress". This study was supported by SUBAPK (17401095).

\section{REFERENCES}

1. Alkan Z. Bilgisayarlı tomografi. Veteriner Radyoloji. Ankara. Mina Ajans Bask. ; 1999: 94-105.

2. Anonim 2017a. http://radyoloji.blogcu.com/temel-radyoloji-fizigi_722957.html (Access date: 8 March 2017).

3. Anonim 2017b. http://www.4cmedikal.com.tr/mimics. asp (Access date: 8 March 2017).

4. Bahar S, Bolat D, Dayan MO, et al. Two- and three-dimensional anatomy of paranasal sinuses in Arabian foals. $J$ Vet Med Sci. 2014; 76(1): 37-44, doi: 10.1292/jvms.13-0172, indexed in Pubmed: 24004969.

5. Bahar S, Dayan MO. Two and three-dimensional computed tomographic anatomy of the guttural pouch in arabian foals. J Animal Vet Adv. 2014; 13: 694-70.

6. lack CR. Geometric morphometric analysis of skeletal shape variation across the pleuronectiformes, Master Thesis, University of Northern lowa, A B D. 2014: 39-42.

7. Capello V, Cauduro A. Clinical technique: application of computed tomography for diagnosis of dental disease in the rabbit, guinea pig, and chinchilla. J Exotic Pet Med. 2008; 17(2): 93-101, doi: 10.1053/j.jepm.2008.03.006.

8. Christensen El, Grann B, Kristoffersen IB, et al. Three-dimensional reconstruction of the rat nephron. Am J Physiol Renal Physiol. 2014; 306(6): F664-F671, doi: 10.1152/ ajprenal.00522.2013, indexed in Pubmed: 24477686.

9. Dayan MO, Besoluk K. Three-dimensional reconstruction from computed tomography images of respiratory system in New Zealand rabbits. J Vet Scien. 2011a; 27(3): 145-148.

10. Dayan MO, Besoluk K. Three-dimensional reconstruction of stomach and intestines in new zealand white rabbits 
from computerized tomography images. Israel J Vet Med. 2011b; 86(3): 108-113.

11. Deleon VB, Smith TD. Mapping the nasal airways: using histology to enhance CT-based three-dimensional reconstruction in Nycticebus. Anat Rec (Hoboken). 2014; 297(11): 2113-2120, doi: 10.1002/ar.23028, indexed in Pubmed: 25312369.

12. Dursun N. Veteriner anatomi I, Ankara, Medisan Yayınevi. 2008: 1-280.

13. Eken $E$, Gezici $M$. The influence of stomach volume on the liver topography in cats. Anat Histol Embryol. 2002; 31(2): 99-104, indexed in Pubmed: 12047245.

14. Elad D, Einav S. Three-dimensional measurement of biological surfaces. ISPRS J Photogrammetry Remote Sensing. 1990; 45(4): 247-266, doi: 10.1016/09242716(90)90047-f.

15. Freitas Ede, Yoshito P, Silv Jda. Use of Rapid Prototyping and 3D Reconstruction in Veterinary Medicine. Adv Appl Rapid Prototyping Tech Modern Engineering. 2011, doi: $10.5772 / 23303$.

16. Gelsvartas J, 2010. Geometric morphometrics. Availble at: http://homepages. inf. ed. ac. uk/rbf/CVonline/LOC AL COPIES. AV0910/gelsvartas.pdf (Accessed: 3 March 2017).

17. González-Solá M, Al-Khayat HA, Behra M, et al. Zebrafish cardiac muscle thick filaments: isolation technique and three-dimensional structure. Biophys J. 2014; 106(8): 1671-1680, doi: 10.1016/j.bpj.2014.01.050, indexed in Pubmed: 24739166.

18. Guan Y, Yoganandan N, Zhang J, et al. Validation of a clinical finite element model of the human lumbosacral spine. Med Biol Eng Comput. 2006; 44(8): 633-641, doi: 10.1007/ s11517-006-0066-9, indexed in Pubmed: 16937205.

19. Huang JW, Xie MK, Zhang $Y$, et al. Reconstruction of penile urethra with the 3-dimensional porous bladder acellular matrix in a rabbit model. Urology. 2014; 84(6): 1499-1505, doi: 10.1016/j.urology.2014.07.044, indexed in Pubmed: 25306480.

20. Kim M, Huh KH, Yi WJ, et al. Evaluation of accuracy of 3D reconstruction images using multi-detector $\mathrm{CT}$ and cone-beam CT. Imaging Sci Dent. 2012; 42(1): 25-33, doi: 10.5624/ isd.2012.42.1.25, indexed in Pubmed: 22474645.

21. Kumaş A. Radyasyon fiziği ve tıbbi uygulamaları, Ankara, Palme Yayıncılık. 2009: 15-80.

22. Kuru M. Omurgalı hayvanlar, Ankara, Gazi Üniversitesi. 1994: 461-481.

23. Lök S. Sporda doping amaçli kullanılan nandrolonun puberta dönemindeki ratlarin femur ve humerus'u üzerine morfometrik etkisi, Doktora Tezi, Selcuk Üniversitesi, Konya. 2009: 19-54.

24. Lu S, Xu YQ, Zhang YZ, et al. A novel computer-assisted drill guide template for lumbar pedicle screw placement: a cadaveric and clinical study. Int J Med Robot. 2009; 5(2): 184-191, doi: 10.1002/rcs.249, indexed in Pubmed: 19280584.

25. Nomina Anatomica Veterinaria. International committee on veterinary gross anatomical nomenclature. 6th ed (Rev.vers). USA, Pub. By the Ed. Com. Hanover, Columbia, Ghent, Rio de Janeiro. 2017.

26. Nickel R, Schummer A, Seiferle E, et al. The anatomy of the domestic animals, Volume I: The locomotor system. Verlag Paul Parey-Springer Verlag, Berlin. 1986: 9-168.

27. Ohlerth S, Scharf G. Computed tomography in small animals--basic principles and state of the art applications. Vet J.
2007; 173(2): 254-271, doi: 10.1016/j.tvjl.2005.12.014, indexed in Pubmed: 16516508.

28. Onar V, Kahvecioğlu KO, Çebi V. Computed tomographic analysis of the cranial cavity and neurocranium in the German shepherd dog (Alsatian) puppies. Vet Arhiv. 2002; 72(2): 57-66.

29. Özkadif S, Eken E. Three-dimensional reconstruction of multidetector computed tomography images of paranasal sinuses of New Zealand rabbits. Turkish J Vet Animal Scien. 2013; 37: 675-681, doi: 10.3906/vet-1301-53.

30. Özkadif S, Eken E, Kalaycı I. A three-dimensional reconstructive study of pelvic cavity in the New Zealand rabbit (Oryctolagus cuniculus). Scien World J. 2014; 2014: 489854, doi: $10.1155 / 2014 / 489854$, indexed in Pubmed: 25379534.

31. Özkadif S, Eken E, Beşoluk K, et al. Three-dimensional reconstruction of New Zealand rabbit antebrachium by multidetector computed tomography. Iran J Vet Res. 2015; 16(2): 205-209, indexed in Pubmed: 27175177.

32. Özkadif S. Üç boyutlu rekonstrüksiyon kullanılarak yapılan bazı veteriner anatomik çalışmalar. Batman Üniversitesi Yaşam Bilimleri Dergisi. 2015; 5(2): 288-295.

33. Özkurt A. 2002. Üç boyutlu örneksel veriden yüzey modeli üretimi. Dokuz Eylül Ünv Mühendislik Fak Fen ve Mühendislik Dergisi. 2015; 4: 27-36.

34. Pazvant G, Kahvecioğlu KO. Kobaylarda ön ve arka bacak uzun kemiklerinin homotipik varyasyonları üzerinde araştırmalar. İstanbul Üniversitesi Veteriner Fakültesi Dergisi. 2013; 39(1): 20-32.

35. Pazvant G. Tavşan ve kobaylarda ön ve arka bacak uzun kemiklerinin (humerus, radius, ulna, femur, tibia, fibula, metacarpus ve metatarsus) homotipik varyasyonları üzerinde araştırmalar. Doktora tezi, İstanbul Üniversitesi, ístanbul. 2003: 38-83.

36. Rohlf FJ, Marcus L. A revolution morphometrics. Trends Ecol Evolut. 1993; 8(4): 129-132, doi: 10.1016/01695347(93)90024-j.

37. Souza M, Greenacre C, Avenell J, et al. Diagnosing a Tooth Root Abscess in a Guinea Pig (Cavia porcellus) Using Micro Computed Tomography Imaging. J Exotic Pet Med. 2006; 15(4): 274-277, doi: 10.1053/j. jepm.2006.09.007.

38. Topçu V. Bilgisayarlı tomografide imaj oluşumu ve gösterimi. Üç boyutlu (3B) imaj işletme ve gösterim teknikleri. İstanbul. TC Sağlık Bakanlığı Taksim Eğitim ve Araştırma Hastanesi Radyodiagnostik Kliniği. Uzmanlık tezi. 2005: 11-15.

39. Wehausen JD, Ramey RR. Cranial morphometric and evolutionary relationships in the northern range of ovis canadensis. J Mammal. 2000; 81(1): 145-161, doi: 10.1093/jmammal/81.1.145.

40. Witkowska A, Alibhai A, Hughes $C$, et al. Computed tomography analysis of guinea pig bone: architecture, bone thickness and dimensions throughout development. PeerJ. 2014; 2: e615, doi: 10.7717/peerj.615, indexed in Pubmed: 25289194.

41. Yavru N, Yavru S. Deney hayvanları, Konya, Selçuk Üniversitesi Veteriner Fakültesi Yayın Ünitesi. 2000: 143-162.

42. Yin H-X, Zhao T, Liu B, et al. Visualization of guinea pig cochleae with computed tomography of diffraction enhanced imaging and comparison with histology. J X-Ray Scien Technol. 2007; 15(2): 73-84. 